ANL/EAIS/TM- -94

DE93 013113

ANLEAIS/TM-94

\title{
Derivation of Strontium-90 and Cesium-137 Residual Radioactive Material Guidelines for the Laboratory for Energy-Related Health Research, University of California, Davis
}

by M. Nimmagadda and C. Yu

Environmental Assessment and Information Sciences Division, Argonne National Laboratory, 9700 South Cass Avenue, Argonne, Illinois 60439

April 1993

Work sponsored by United States Department of Energy

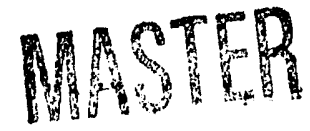




\section{CONTENTS}

NOTATION $\ldots \ldots \ldots \ldots \ldots \ldots \ldots \ldots \ldots \ldots \ldots \ldots \ldots \ldots \ldots$ iv

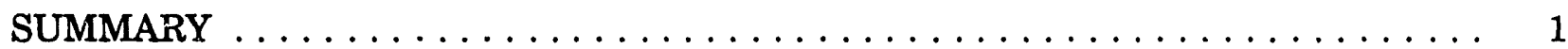

1 INTRODUCTION AND BRIEF HISTORY $\ldots \ldots \ldots \ldots \ldots \ldots \ldots$

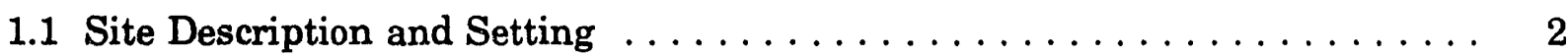

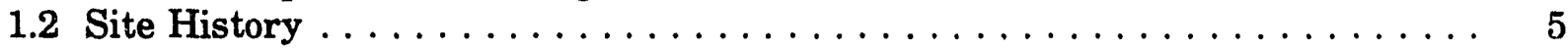

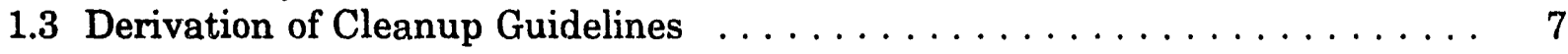

2 SCENARIO DEFINITIONS $\ldots \ldots \ldots \ldots \ldots \ldots \ldots \ldots \ldots \ldots$

3 DOSE/SOURCE CONCENTRATION RATIOS $\ldots \ldots \ldots \ldots \ldots \ldots \ldots \ldots$

4 RESIDUAL RADIOACTIVE MATERIAL GUIDELINES . . . . . . . . . . . . . . 13

$5 \quad \operatorname{REFERENCES} \ldots \ldots \ldots \ldots \ldots \ldots \ldots \ldots \ldots \ldots \ldots \ldots \ldots \ldots \ldots$

APPENDIX: Parameters Used in the Analysis of the LEHR Site $\ldots \ldots \ldots \ldots$

\section{FIGURES}

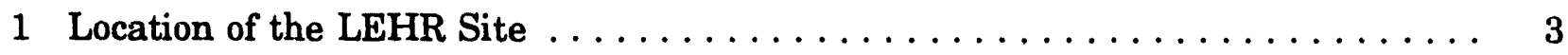

2 Map of the LEHR Site $\ldots \ldots \ldots \ldots \ldots \ldots \ldots \ldots \ldots \ldots \ldots \ldots$

\section{TABLES}

1 Summary of Pathways for Scenarios A, B, and C at the LEHR Site ....... 9

2 Maximum Dose/Source Concentration Ratios for Strontium-90 for Scenarios A, B, and $\mathbf{C}$ at the LEHR Site $\ldots \ldots \ldots \ldots \ldots \ldots$

3 Maximum Dose/Source Concentration Ratios for Cesium-137 for Scenarios A, B, and $C$ at the LEHR Site . . . . . . . . . . . . 12

4 Residual Radioactive Material Guidelines for Strontium-90 and Cesium-137 at the LEHR Site $\ldots \ldots \ldots \ldots \ldots \ldots$

A.1 Parameters Used in the RESRAD Code for Analysis of the LEHR Site . . . . . . 18 


\section{NOTATION}

The following is a list of the acronyms, initialisms, and abbreviations (including units of measure) used in this document. Some acronyms used in tables or equations only are defined in the respective tables or equations.

\section{ACRONYMS, INITIALISMS, AND ABBREVIATIONS}

AEC U.S. Atomic Energy Commission

ALARA as low as reasonably achievable

CERCLA Comprehensive Environmental Response, Compensation, and Liability Act of 1980 , as amended

DOE U.S. Department of Energy

ERDA U.S. Energy Research and Development Administration

LEHR Laboratory for Energy-Related Health Research

NPL National Priorities List

RESRAD residual radioactive material guideline computer code

SARA Superfund Amendments and Reauthorization Act of 1986

UCD University of California, Davis

\section{UNITS OF MEASURE}

$\begin{array}{ll}{ }^{\circ} \mathrm{C} & \text { degrees Celsius } \\ { }^{\circ} \mathrm{F} & \text { degrees fahrenheit } \\ \mathrm{cm} & \text { centimeter(s) } \\ \mathrm{cm}^{3} & \text { cubic centimeter(s) } \\ \mathrm{d} & \text { day(s) } \\ \mathrm{ft} & \text { foot (feet) } \\ \mathrm{ft}^{2} & \text { square foot (feet) } \\ \mathrm{g} & \text { gram(s) } \\ \mathrm{h} & \text { hour(s) } \\ \mathrm{ha} & \text { hectare(s) } \\ \text { in. } & \text { inch(es) } \\ \mathrm{kg} & \text { kilogram(s) }\end{array}$

$\begin{array}{ll}\mathbf{k m} & \text { kilometer(s) } \\ \mathrm{L} & \text { liter(s) } \\ \mathbf{m} & \text { meter(s) } \\ \mathbf{m}^{2} & \text { square meter(s) } \\ \mathbf{m i} & \text { mile(s) } \\ \mathrm{mrem} & \text { millirem(s) } \\ \mathrm{pCi} & \text { picocurie(s) } \\ \mathrm{rem} & \text { roentgen equivalent man } \\ \mathrm{s} & \text { second(s) } \\ \mathrm{yd}^{2} & \text { square yard(s) } \\ \mathrm{yr} & \text { year(s) }\end{array}$




\section{DERIVATION OF STRONTIUM-90 AND CESIUM-137 RESIDUAL RADIOACTIVE MATERIAL GUIDELINES FOR THE LABORATORY FOR ENERGY-RELATED HEALTH RESEARCH, UNIVERSITY OF CALIFORNIA, DAVIS}

by

M. Nimmagadda and C. Yu

\section{SUMMARY}

Residual radioactive material guidelines for strontium-90 and cesium-137 were derived for the Laboratory for Energy-Related Health Research (LEHR) site in Davis, California. The guideline derivation was based on a dose limit of $100 \mathrm{mrem} / \mathrm{yr}$. The U.S. Department of Energy (DOE) residual radioactive material guideline computer code, RESRAD, was used in this evaluation; this code implements the methodology described in the DOE manual for implementing residual radioactive material guidelines. Three potential site utilization scenarios were considered with the assumption that, for a period of 1,000 years following remedial action, the site will be utilized without radiological restrictions. The defined scenarios vary with regard to use of the site, time spent at the site, and sources of food consumed. The results of the evaluation indicate that the basic dose limit of $100 \mathrm{mrem} / \mathrm{yr}$ will not be exceeded within 1,000 years for either strontium-90 or cesium-137, provided that the soil concentrations of these radionuclides at the LEHR site do not exceed the following levels: $71,000 \mathrm{pCi} / \mathrm{g}$ for strontium- 90 and $91 \mathrm{pCi} / \mathrm{g}$ for cesium-137 for Scenario $\mathrm{A}$ (researcher: the expected scenario); $160,000 \mathrm{pCi} / \mathrm{g}$ for strontium-90 and $220 \mathrm{pCi} / \mathrm{g}$ for cesium-137 for Scenario B (recreationist: a plausible scenario); and $37 \mathrm{pCi} / \mathrm{g}$ for strontium-90 and $32 \mathrm{pCi} / \mathrm{g}$ for cesium-137 for Scenario $\mathrm{C}$ (resident farmer ingesting food produced in the contaminated area: a plausible scenario). The derived guidelines are single-radionuclide guidelines and are linearly proportional to the dose limit used in the calculations. In setting the actual strontium-90 and cesium-137 guidelines for the LEHR site, DOE will apply the as low as reasonably achievable (ALARA) policy to the decision-making process, along with other factors such as whether a particular scenario is reasonable and appropriate. 


\section{INTRODUCTION AND BRIEF HISTORY}

The Laboratory for Energy-Related Health Research (LEHR) is part of the University of California, Lavis (UCD), and is located on the campus. A variety of operations involving the use of radioactive materials were conducted at the site between 1958 and 1988. Potential contaminated areas exist at the site from past disposal practices associated with UCD campus activities and with research activities at LEHR sponsored by the U.S. Department of Energy (DOE). The DOE is proposing to conduct remedial action at the LEHR site and to verify that conditions following remedial action comply with current federal guidelines.

The LEHR facility is currently proposed to be on the National Priorities List (NPL) under the Comprehensive Environmental Response, Compensation, and Liability Act (CERCLA) of 1980, as amended by the Superfund Amendments and Reauthorization Act (SARA) of 1986. A preliminary assessment of the LEHR facility was completed in 1988, and the hazard ranking system process is currently being completed by the U.S. Environmental Protection Agency (Dames \& Moore 1993). Depending on the ranking, an investigation at the site could be required to comply with the formal remedial investigation process under CERCLA. However, at this time, the site is not under any regulatory enforcement action.

The proposed remedial action for the site will follow the guidelines established in DOE Order 5400.5 (DOE 1990). The residual radioactive (RESRAD) material guideline computer code (Gilbert et al. 1989) is used to derive residual radioactive material guidelines on a site-specific basis. This report presents the strontium-90 and cesium-137 guidelines derived for the LEHR site; the derivation of these guidelines was based on the requirement that the 50-year committed effective dose equivalent to a hypothetical individual who lives or works in the immediate vicinity of the LEHR site should not exceed a dose of $100 \mathrm{mrem} / \mathrm{yr}$ following remedial action.

\subsection{SITE DESCRIPTION AND SETTING}

The LEHR site is located on the southeast portion of the UCD campus in Solano County, California. The site is approximately $2.4 \mathrm{~km}(1.5 \mathrm{mi})$ south of the main UCD campus and the town of Davis and approximately $1.2 \mathrm{~km}(0.7 .5 \mathrm{mi})$ south of Interstate 80 on County Road 79 (Figure 1). The LEHR site covers approximately 6.1 ha (15 acres) and contains several buildings, including a main administration and office building, two animal hospitals, laboratory and support buildings, waste-handling facilities, and numerous outside dog pens (Figure 2). The land is owned by the Regents of the University of California and leased to the DOE; the structures at LEHR are owned by DOE (DOE 1988).

Also located on the LEHR site are two inactive landfills: the old UCD landfill, closed in 1966, and a campus and DOE low-level radioactive waste disposal site, closed in 1974

(Figure 2). A third inactive landfill unit is located approximately $180 \mathrm{~m}$ (600 ft) east of LEHR below the area currently occupied by the UCD Raptor Center. 


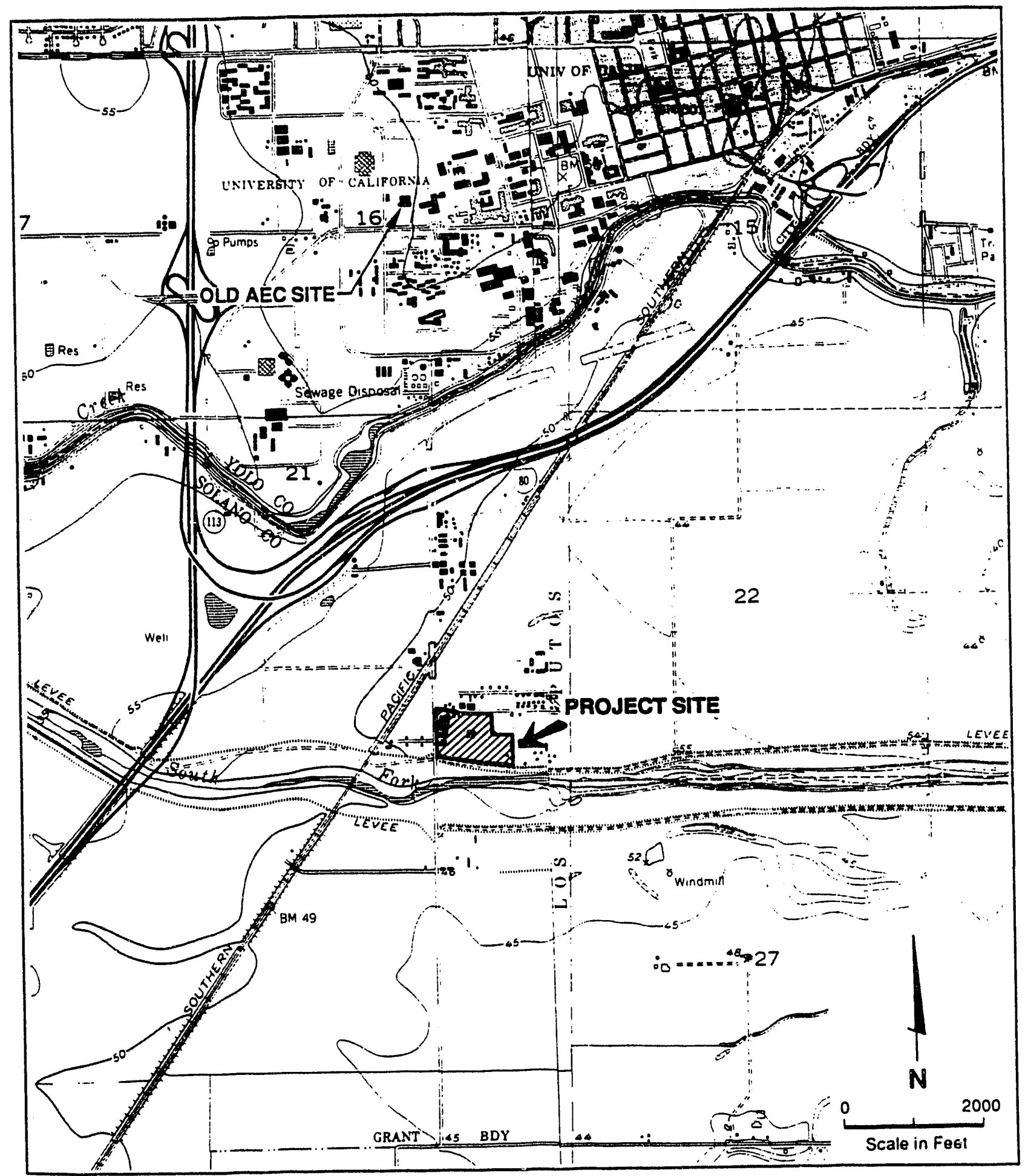

FIGURE 1 Location of the LEHR Site (Source: Modified from Dames \& Moore 1993) 


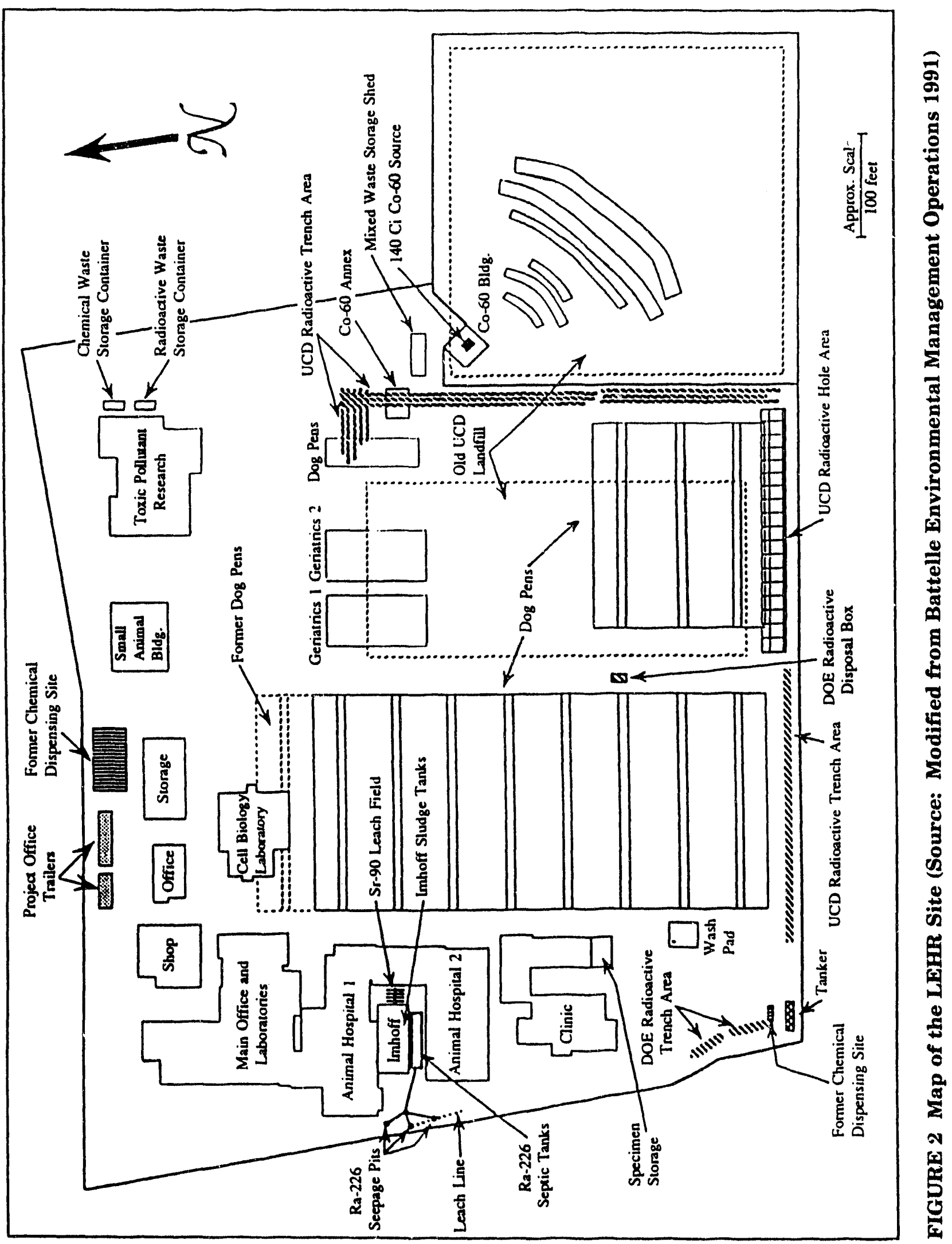


The LEHR site is located in a rural area and is bounded on all sides by UCD property. The southern border of the LEHR facility is the northern levee of the South Fork of Putah Creek. Private land surrounds the UCD property on all sides. Land use in the vicinity of UCD and the LEHR facility is predominantly agricultural. Approximately $60 \%$ of Solano County's total area is farmland, and $18 \%$ of the total land is irrigated cropland (U.S. Bureau of the Census 1989). The current population of Davis is approximately 46,000, and the current population of Solano County is about 340,400 (U.S. Bureau of the Census 1991).

Surface soil at the LEHR facility is classified in the Reiff series as a fine sandy loam. The dominant texture of the upper subsoil is sandy, and the dominant texture of the lower subsoil is gravelly, loamy (silty) sand. The soil is characterized by a deep, permeable profile and good drainage (Dames \& Moore 1993).

Groundwater beneath the site ranges in depth from approximately 13.7 to $21.3 \mathrm{~m}$ ( 45 to $70 \mathrm{ft}$ ) below ground surface and has been divided into two zones (Dames \& Moore 1993). The first hydrostratigraphic unit consists of fine-grained sediment varying from very fine grained sandy silt to sandy clay, and the second hydrostratigraphic unit consists of coarse sand and cobble gravel. Because of the agricultural use of nearby land, many domestic and supply wells are located close to the LEHR facility; however, no active groundwater wells are present on the LEHR site.

The climate in the region of the LEHR facility is temperate, with mild winters and long summers. The average temperature is $8.3^{\circ} \mathrm{C}\left(46.9^{\circ} \mathrm{F}\right)$ in winter and $23^{\circ} \mathrm{C}\left(73^{\circ} \mathrm{F}\right)$ in summer (National Oceanic and Atmospheric Administration 1985; DOE 1988). The mean annual precipitation at the Davis Meteorological Station is $43 \mathrm{~cm}$ (17.0 in.), most of which occurs between October and April (National Climatic Data Centers 1992). Since the winter of 1986-1987, most of California, including the Davis area, has experienced drought conditions. Regionally, the drought has resulted in decreased aquifer recharge, and groundwater levels have decreased due to the effects of drought and pumping for agricultural, municipal, and industrial uses.

\subsection{SITE HISTORY}

The UCD has conducted radiological studies on laboratory animals for the DOE since the 1950s. The initial studies, conducted for the U.S. Atomic Energy Commission (AEC, now DOE), involved the X-irradiation of beagles at the UCD main campus. Eventually, $\mathrm{X}$-irradiation experiments were discontinued at the AEC project site, and the site was then used to house the breeding colony that supplied beagles for future studies at LEHR. The former AEC site is currently occupied by the UCD police and fire department offices, a dormitory, parking areas, and an open field.

Other experiments associated with the AEC programs at UCD were conducted at remote locations. During the construction phase of the LEHR facility from 1958 to 1960 , 
pilot-scale tests using strontium-90 were conducted in temporary buildings at the Davis Airport and at a site currently occupied by Robbins Hall on the main UCD campus. In the middle and late 1960s, several programs were conducted at the UCD Hopland Field Station.

Full-scale experimental use of radioactive materials - including strontium-90, radium-226, and cesium-137 - began at LEHR in 1960. In the initial stages of operation at the LEHR facility, waste was handled through a central waste-handling facility on the main campus. However, because of safety concerns, waste handling for LEHR-generated waste was returned to the LEHR facility in the early 1960 s.

Portions of the LEHR site had previously been used as the UCD campus landfill, which consisted of two separate disposal units. Disposal in the oldest unit (Inactive Disposal Unit No. 1) began in the 1940 s and ceased in the late 1950 s to early 1960 s. The area is now covered by the cobalt-60 source field at the LEHR facility (Figure 2). The next oldest disposal area (Inactive Disposal Unit No. 2) received wastes from 1956 to 1967 . This disposal area is partially covered with the easternmost of "wo sets of dog pens used to house the beagles for animal research at the LEHR facility. A third landfill disposal unit, located about $180 \mathrm{~m}$ $(600 \mathrm{ft}$ ) east of LEHR (Inactive Disposal Unit No. 3), was used from 1963 to 1967.

Laboratory research continued through sponsorship of the U.S. Energy Research and Development Administration (ERDA, predecessor to DOE) and DOE until funding for the DOE-related work was terminated in FY 1988 (except for limited data evaluation). During the 30-year operation of the LEHR facility, various wastes were generated and disposed of on-site. These wastes included radioactive, biological, chemical, municipal, and laboratory debris.

In late 1984, Rockwell International was contracted by DOE to perform an initial survey of the LEHR facility. The purpose of this survey was to obtain initial characterization data on the nature and extent of radioactive and chemical contamination at the site (Rockwell International 1984).

In 1987, a DOE team conducted an environmental survey of the facility to identify environmental problems and risks associated with LEHR. This survey concluded that several potential environmental threats existed at the LEHR facility. Waste burial sites and the Imhoff treatment tanks, septic system, and associated leach fields were considered to be potential sources of chemical and radioactive leachate to groundwater. Additionally, dog pen and cobalt-60 irradiation activities were considered to be potential sources of soil contamination (DOE 1988).

During 1987 and 1988, Wahler Associates conducted a groundwater and soils investigation at LEHR, now termed the Phase I study, to evaluate chemical and radioactive contamination in the soils and groundwater at the site. The purpose of this study was to provide a basis for subsequent investigations and monitoring at the site (Wahler Associates 1988, 1989). 
In early 1990, Dames \& Moore began a Phase II site characterization study. The results of this survey indicated the presence of residual radioactive contamination, primarily radium-226 and strontium-90, in on-site soil (Dames \& Moore 1993). A maximum concentration of $19 \mathrm{pCi} / \mathrm{g}$ of strontium-90 was detected in one sample from the northern part of LEHR; maximum concentrations of $0.61,0.70,0.22$, and $0.10 \mathrm{pCi} / \mathrm{g}$ of strontium-90 were detected in the radium-226 seepage pits, southwest chemical-dispensing area, dog pen area, and north chemicai-dispensing area, respectively. No strontium-90 was reported in samples analyzed from the strontium-90 leach field or the old AEC project site. Average background soil concentrations of strontium-90 ranged from nondetectable to $0.24 \mathrm{pCi} / \mathrm{g}$. Cesium-137 was detected in the radium-226 seepage pits, dog pen area, and strontium-90 leach field area. The cesium-137 concentrations at these three areas were at or below the maximum measured background concentration of $0.2 \mathrm{pCi} / \mathrm{g}$.

\subsection{DERIVATION OF CLEANUP GUIDELINES}

Most DOE cleanup guidelines applicable to remedial actions are generic in nature, including the guideline for radium-226 in soil; however, guidelines for strontium-90 and cesium-137 in soil are derived on a site-specific basis (DOE 1990, 1992). The purpose of this report is to present the residual radioactive material guidelines derived for strontium-90 and cesium-137 that are applicable to remedial action at the LEHR site - that is, the residual concentrations of strontium-90 and cesium-137 in a homogeneously contaminated area that must not be exceeded if the site is to be released for use without radiological restrictions. The derivation of site-specific, single-radionuclide strontium-90 and cesium-137 guidelines for the LEHR site is based on a dose limit of $100 \mathrm{mrem} / \mathrm{yr}$ (DOE 1990, 1992) and the assumption that strontium-90 or cesium-137 is the only radionuclide present at an above-background concentration. The RESRAD computer code, which implements the methodology described in the DOE manual for implementing residual radioactive material guidelines (Gilbert et al. 1989), was used to derive these guidelines. 


\section{SCENARIO DEFINITIONS}

Three potential exposure scenarios are considered for the LEHR site. All scenarios assume that, at some time within 1,000 years, the site will be released for use without radiological restrictions following remedial action.

Scenario A (the expected scenario) assumes research use of the site. Under this scenario, a hypothetical individual is assumed to work in the area of the site for 8 hours per day ( 6 hours outdoors and 2 hours indoors), 5 days per week, 50 weeks per year. Therefore, in 1 year, the research worker is assumed to spend $17 \%$ of the time working outdoors at the site, $6 \%$ of the time working indoors at the site, and $77 \%$ of the time away from the site. It is assumed that the worker does not ingest water, plant foods, or fish obtained from the decontaminated area, or meat or milk from livestock raised in the decontaminated area.

Scenario B (a plausible scenario) assumes recreational use of the site. Under this scenario, it is assumed that, at some time in the future, the whole site is transformed into a public recreational park and a hypothetical individual spends 15 hours per week, 50 weeks per year, in the decontaminated area of the park. Therefore, in 1 year, this generic recreationist is assumed to spend $9 \%$ of the time in the decontaminated area and $91 \%$ of the time away from the site. It is assumed that the recreationist does not ingest water or plant foods obtained from the decontaminated area, or meat or milk from livestock raised in the decontaminated area. Also, it is assumed that any fish or other aquatic food consumed by the recreationist is not obtained from the site.

Scenario C (a plausible scenario) assumes agricultural use of the site. Under this scenario, it is assumed that, at some time in the future, the whole site is transformed into a farm and, in 1 year, a hypothetical resident farmer spends $50 \%$ of the time indoors in the decontaminated area, $25 \%$ of the time outdoors in the decontaminated area, and $25 \%$ of the time away from the site. The resident farmer is assumed to ingest plant foods grown in the garden and fish and other aquatic food obtained from the site. This individual is also assumed to ingest meat and milk obtained from livestock raised in the decontaminated area. The resident's drinking water supply is assumed to be from an on-site well.

Potential radiation doses resulting from eight exposure pathways are analyzed:

- Direct exposure to external gamma radiation from the decontaminated soil material;

- Internal radiation from inhalation of contaminated dust;

- Internal radiation from ingestion of plant foods grown in the decontaminated area and irrigated with water from local groundwater wells; 
- Internal radiation from ingestion of meat obtained from livestock fed with fodder grown in the decontaminated area and with water drawn from inside the area;

- Internal radiation from ingestion of milk obtained from livestock fed with fodder grown in the decontaminated area and with water drawn from inside the area;

- Internal radiation from ingestion of water drawn from inside the area;

- Internal radiation from ingestion of fish and other aquatic food obtained from the site; and

- Internal radiation from ingestion of on-site soil.

All pathways considered for Scenarios A, B, and C are summarized in Table 1.

TABLE 1 Summary of Pathways for Scenarios A, B, and C at the LEHR Site

\begin{tabular}{lccc}
\hline \multicolumn{1}{c}{ Pathway } & $\begin{array}{c}\text { Scenario A } \\
\text { (Researcher) }\end{array}$ & $\begin{array}{c}\text { Scenario B } \\
\text { (Recreationist) }\end{array}$ & $\begin{array}{c}\text { Scenario C } \\
\text { (Resident Farmer) }\end{array}$ \\
\hline External gamma exposure & Yes & Yes & Yes \\
Inhalation of dust & Yes & Yes & Yes \\
Ingestion of plant foods & No & No & Yes \\
Ingestion of meat & No & No & Yes \\
Ingestion of milk & No & No & Yes \\
Ingestion of fish & No & No & Yes \\
Ingestion of soil & Yes & Yes & Yes \\
Ingestion of water & No & No & Yes \\
\hline
\end{tabular}

In using the RESRAD computer code (Gilbert et al. 1989) to calculate potential radiation doses to the hypothetical future researcher, recreationist, or resident farmer, the following assumptions were made for these scenarios:

- During 1 year, the researcher spends 1,500 hours (17\%) outdoors at the site, 500 hours $(6 \%)$ indoors at the site, and 6,760 hours $(77 \%)$ away from the decontaminated area; the recreationist spends 750 hours $(9 \%)$ per year on-site; and the resident farmer spends 4,380 hours $(50 \%)$ indoors, 2,190 hours (25\%) outdoors in the decontaminated area, and 2,190 hours $(25 \%)$ away from the site. 
- The walls, floors, and foundation of the house or office building reduce external exposure by $30 \%$.

- The indoor dust level in the house or office building is $40 \%$ of the outdoor dust level (Gilbert et al. 1989).

- $50 \%$ of the plant food diet consumed by the resident farmer is grown in a garden in the decontaminated area. Neither the researcher nor the recreationist consumes these plant foods.

- The size of the decontaminated area is sufficient to grow all of the forage needed for raising livestock in the decontaminated area to produce sufficieni meat and milk for the resident farmer. Neither the researcher nor the recre ationist consumes this meat or milk.

- $50 \%$ of the fish and other aquatic food consumed by the farmer is obtained from the site. Neither the researcher nor the recreationist consumes aquatic food obtained from the site.

- After remedial action, no cover material is placed over the decontaminated area.

- The thickness of the contaminated zone is a conservative average value derived from Dames \& Moore (1993) measurements. The whole area of the LEHR site $\left(60,700 \mathrm{~m}^{2}\left[653,400 \mathrm{ft}^{2}\right]\right)$ is conservatively assumed to be

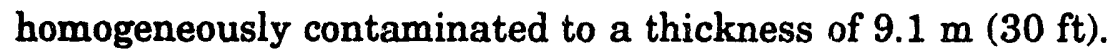




\section{DOSE/SOURCE CONCENTRATION RATIOS}

The RESRAD computer code (Gilbert et al. 1989) was used to calculate the dose/ source concentration ratio $\operatorname{DSR}_{p}(t)$ for strontium-90 and cesium-137 for pathway $p$ and at time $t$ after remedial action. The time frame considered in this analysis was 1,000 years. Radioactive decay were considered in deriving the dose/source concentration ratios. The various parameters used in the RESRAD code for this analysis for Scenarios A, B, and C are listed in the Appendix. The calculated maximum dose/source concentration ratios for all pathways are presented in Table 2 for strontium-90 and Table 3 for cesium-137. For each scenario, the maximum dose/source concentration ratios would occur at time zero (immediately after remedial action). For strontium-90, the primary pathways for Scenarios A and $B$ are inhalation of particulates and ingestion of soil; the primary pathway for Scenario $C$ is ingestion of plant foods. For cesium-137, the primary pathway is external gamma irradiation for all three scenarios. For both radionuclides, contributions from their short-lived decay products are implicitly taken into account in the calculations.

TABLE 2 Maximum Dose/Source Concentration Ratios for Strontium-90 for Scenarios A, B, and $C$ at the LEHR Site

\begin{tabular}{|c|c|c|c|}
\hline \multirow[b]{2}{*}{ Pathway } & \multicolumn{3}{|c|}{$\begin{array}{c}\text { Maximum Dose/Source Concentration Ratio }{ }^{\mathrm{a}} \\
(\mathrm{mrem} / \mathrm{yr}) /(\mathrm{pCi} / \mathrm{g})\end{array}$} \\
\hline & Scenario A & Scenario B & Scenario C \\
\hline External gamma exposure & 0 & 0 & 0 \\
\hline Inhalation of dust & $4.2 \times 10^{-4}$ & $1.9 \times 10^{-4}$ & $9.7 \times 10^{-4}$ \\
\hline Ingestion of plant foods & 0 & 0 & 2.4 \\
\hline Ingestion of meat & 0 & 0 & $3.6 \times 10^{-2}$ \\
\hline Ingestion of milk & 0 & 0 & $2.1 \times 10^{-1}$ \\
\hline Ingestion of fish & 0 & 0 & 0 \\
\hline Ingestion of soil & $9.9 \times 10^{-4}$ & $4.4 \times 10^{-4}$ & $2.3 \times 10^{-3}$ \\
\hline Ingestion of water & 0 & 0 & 0 \\
\hline Total & $1.4 \times 10^{-3}$ & $6.3 \times 10^{-4}$ & 2.7 \\
\hline
\end{tabular}

a Maximum dose/source concentration ratios would occur at time zero (immediately following remedial action); all values are reported to two significant figures. 
TABLE 3 Maximum Dose/Source Concentration Ratios for Cesium-137 for Scenarios A, B, and $C$ at the LEHR Site

\begin{tabular}{|c|c|c|c|}
\hline \multirow[b]{2}{*}{ Pathway } & \multicolumn{3}{|c|}{$\begin{array}{l}\text { Maximum Dose/Source Concentration Katio }{ }^{\mathrm{a}} \\
(\mathrm{mrem} / \mathrm{yr}) /(\mathrm{pCi} / \mathrm{g})\end{array}$} \\
\hline & Scenario A & Scenario B & Scenario C \\
\hline External gamma exposure & 1.1 & $4.5 \times 10^{-1}$ & 3.1 \\
\hline Inhalation of dust & $1.0 \times 10^{-5}$ & $4.6 \times 10^{-6}$ & $2.4 \times 10^{-5}$ \\
\hline Ingestion of plant foods & 0 & 0 & $8.7 \times 10^{-3}$ \\
\hline Ingestion of meat & 0 & 0 & $1.3 \times 10^{-2}$ \\
\hline Ingestion of milk & 0 & 0 & $2.6 \times 10^{-3}$ \\
\hline Ingestion of fish & 0 & 0 & 0 \\
\hline Ingestion of soil & $3.5 \times 10^{-4}$ & $1.6 \times 10^{-4}$ & $8.2 \times 10^{-4}$ \\
\hline Ingestion of water & 0 & 0 & 0 \\
\hline Total & 1.1 & $4.5 \times 10^{-1}$ & 3.1 \\
\hline
\end{tabular}

a Maximum dose/source concentration ratios would occur at time zero (immediately following remedial action); all values are reported to two significant figures.

The summation of $\operatorname{DSR}_{i p}(t)$ for all pathways $p$ is the $\operatorname{DSR}_{i}(t)$ for the $i^{i \text { h }}$ isotope, i.e.,

$$
D S R_{i}(t)=\sum_{p} D S R_{i p}(t) .
$$

The total dose/source concentration ratios for strontium-90 and cesium-137 are provided in Tables 2 and 3, respectively. These ratios were used to determine the allowable residual radioactivity fer strontium -90 and cesium -137 at the LEHR site. 


\section{RESIDUAL RADIOACTIVE MATERIAL GUIDELINES}

The residual radioactive material guideline is the concentration of residual radioactive material that can remain in a decontaminated area and still allow use of the area without radiological restrictions. On the basis of the DOE annual radiation dose limit of $100 \mathrm{mrem} / \mathrm{yr}$ for an individual (DOE 1990, 1992), the single-radionuclide residual radioactive material guideline $G_{i}$ for strontium- 90 or cesium- 137 at the LEHR site can be calculated as

$$
G_{i}=100 / D S R_{i},
$$

where $\mathrm{DSR}_{\mathrm{i}}$ is the total dose/source concentration ratio listed in Table 2 or Table 3, respectively. The calculated residual radioactive material guidelines for strontium-90 and cesium-137 at the LEFR site are presented in Table 4. The derived guidelines are linearly proportional to the dose limit used in the calculation.

When implementing the derived radionuclide guidelines for decontamination of a site, the sum-of-fractions rule applies. That is, the summation of the fractions of radionuclide concentrations $S_{i}$ remaining on-site, averaged over an area of $100 \mathrm{~m}^{2}\left(120 \mathrm{yd}^{2}\right)$ and a depth of $15 \mathrm{~cm}\left(6 \mathrm{in}\right.$.) and divided by their guidelines $\mathrm{G}_{\mathrm{i}}$, should not be greater than unity, or

$$
\sum_{i} S_{i} / G_{i} \leq 1 \text {. }
$$

The derived strontium-90 and cesium-137 guidelines for the LEHR site are singleradionuclide guidelines for a large, homogeneously contaminated area. For a small isolated area of contamination, the allowable concentration that can remain on-site may be higher than the homogeneous guideline, depending on the size of the area of contamination.

In setting the actual strontium-90 and cesium-137 guidelines for the LEHR site, DOE will apply the as low as reasonably achievable (ALARA) policy to the decision-making process, along with other factors such as whether a particular scenario is reasonable and appropriate.

TABLE 4 Residual Radioactive Material Guidelines for Strontium-90 and Cesium-137 at the LEHR Site

\begin{tabular}{lcc}
\hline & \multicolumn{2}{c}{ Guideline $^{\mathrm{a}}(\mathrm{pCi} / \mathrm{g})$} \\
\cline { 2 - 3 } Scenario & Strontium-90 & Cesium-137 \\
\hline A: Researcher & 71,000 & 91 \\
B: Recreationist & 160,000 & 220 \\
C: Resident farmer & 37 & 32 \\
\hline
\end{tabular}

a All values are reported to two significant figures. 


\section{REFERENCES}

Battelle Environmental Management Operations, 1991, Laboratory for Energy-Related Health Research, University of California, Davis; Environmental Restoration Project, Project Plan, prepared by J.N. Hartley and S. Attiga, Battelle Environmental Management Operations, for U.S. Department of Energy, San Francisco Operations Office, San Francisco, Calif., July.

Dames \& Moore, 1993, Phase II Site Characterization Report for the LEHR Environmental Restoration, University of California at Davis, Volumes I, II and III, prepared by Dames \& Moore, Sacramento, Calif., for U.S. Department of Energy, Environmental Management Operations, Richland, Wash., Feb.

DOE: see U.S. Department of Ene:gy.

Gilbert, T.L., et al., 1989, A Manual for Implementing Residual Radioactive Material Guidelines, ANL/ES-160 (DOE/CH/8901), prepared by Argonne National Laboratory, Argonne, Ill., for U.S. Department of Energy, Washington, D.C., June.

National Oceanic and Atmospheric Administration, 1985, Local Climatological Data 1985, Sacramento, California, National Climatic Data Centers, Asheville, N.C.

National Climatic Data Centers, 1992, National Oceanic and Atmospheric Administration Database, information obtained through the University of Nevada Desert Research Institute, Western Regional Climate Data Center (Davis 2 WSW station).

Rockwell International, 1984, Initial Assessment Survey of the DOE LEHR Site of University of California-Davis, AI-DOE-13504, prepared by Rockwell International, Canoga Park, Calif., for U.S. Department of Energy, Oct. 31.

U.S. Bureau of the Census, 1989, 1987 Census of Agriculture, Volume 1, Part 5, U.S. Department of Commerce, Washington, D.C.

U.S. Bureau of the Census, 1991, Summary of Population and Housing Characteristics, CPH 1-6, U.S. Department of Commerce, Washington, D.C.

U.S. Department of Energy, 1988, Environmental Survey Preliminary Report Laboratory for Energy-Related Health Research, Davis, California, DOE/EH/OEV-28-P, Office of Environmental Audit of the Office of Environment, Safety and Health, Washington, D.C., March.

U.S. Department of Energy, 1990, Radiation Protection of the Public and Environment, DOE Order 5400.5, Feb.

U.S. Department of Energy, 1992, Radiological Control Manual, Washington, D.C., June. 
Wahler Associates, 1988, Groundwater and Soils Investigation, U.C. Davis Research Facility, Davis, California, prepared by Wahler Associates, Palo Alto, Calif., for University of California, Davis, Dec.

Wahler Associates, 1989, Groundwater and Soils Investigation, U.C. Davis LEHR Facility, Davis, California, Volumes I and II, prepared by Wahler Associates, Palo Alto, Calif., for University of California, Davis, May. 


\section{APPENDIX:}

\section{PARAMETERS USED IN THE ANALYSIS OF THE LEHR SITE}

The parametric values used in the RESRAD code for the analysis of the LEHR site are listed in Table A.1. All parametric values are reported at up to three significant figures. Some values are specific to the LEHR site; others are generic. The assumptions for each of these scenarios are as follows:

- Scenario A: Continued research use of the site. A hypothetical person is assumed to work in the area of the site.

- Scenario B: Recreational use of the site. A hypothetical recreationist is assumed to spend some time during the year at a public park constructed on the decontaminated area.

- Scenario C: Residential use of the site. A hypothetical resident farmer is assumed to live in the decontaminated area. 
TABLE A.1 Parameters Used in the RESRAD Code for Analysis of the LEHR Site

\begin{tabular}{|c|c|c|c|c|}
\hline \multirow[b]{2}{*}{ Parameter } & \multirow[b]{2}{*}{ Unit } & \multicolumn{3}{|c|}{ Value } \\
\hline & & Scenario A & Scenario B & Scenario $\mathrm{C}$ \\
\hline Area of contaminated zone $e^{a}$ & $\mathrm{~m}^{2}$ & 60,700 & 60,700 & 60,700 \\
\hline Thickness of contaminated zone ${ }^{a}$ & m & 9.1 & 9.1 & 9.1 \\
\hline Length parallel to aquifer flow $w^{a}$ & m & Not used & Not used & 246 \\
\hline Cover depth ${ }^{\mathrm{a}}$ & m & 0 & 0 & 0 \\
\hline Density of contaminated zone $e^{a}$ & $\mathrm{~g} / \mathrm{cm}^{3}$ & 1.35 & 1.35 & 1.35 \\
\hline Contaminated zone erosion rate ${ }^{b}$ & $\mathrm{~m} / \mathrm{yr}$ & 0.001 & 0.001 & 0.001 \\
\hline Contaminated zone total porosity ${ }^{a}$ & - & 0.4 & 0.4 & 0.4 \\
\hline Contaminated zone effective porosity & - & 0.2 & 0.2 & 0.2 \\
\hline Contaminated zone hydraulic conductivitya & $\mathrm{m} / \mathrm{yr}$ & 200 & 200 & 200 \\
\hline Contaminated zone b parameter & - & 7.12 & 7.12 & 7.12 \\
\hline Evapotranspiration coefficient ${ }^{b}$ & - & 0.6 & 0.6 & 0.6 \\
\hline Precipitation ${ }^{a}$ & $\mathrm{~m} / \mathrm{yr}$ & 0.43 & 0.43 & 0.43 \\
\hline Irrigation ${ }^{\mathrm{b}}$ & $\mathrm{m} / \mathrm{yr}$ & 0.2 & 0.2 & 0.2 \\
\hline Irrigation mode ${ }^{b}$ & - & Overhead & Overhead & Overhead \\
\hline Runoff coefficient ${ }^{b}$ & - & 0.4 & 0.4 & 0.4 \\
\hline Watershed area for nearby pond ${ }^{a}$ & $\mathrm{~m}^{2}$ & Not used & Not used & $1,000,000$ \\
\hline Density of saturated zone & $\mathrm{g} / \mathrm{cm}^{3}$ & Not used & Not used & 1.7 \\
\hline Saturated zone total porosity ${ }^{a}$ & - & Not used & Not used & 0.4 \\
\hline Saturated zorfe effective porosity & - & Not used & Not used & 0.2 \\
\hline Saturated zone hydraulic conductivity ${ }^{a}$ & $\mathrm{~m} / \mathrm{yr}$ & Not used & Not used & 3,076 \\
\hline Saturated zone hydraulic gradient ${ }^{a}$ & $\cdot$ & Not used & Not used & 0.03 \\
\hline Saturated zone b parameter ${ }^{a}$ & - & Not used & Not used & 7.75 \\
\hline Water table drop rate ${ }^{b}$ & $\mathrm{~m} / \mathrm{yr}$ & Not used & Not used & 0.001 \\
\hline Well pump intake depth (below water table) & m & Not used & Not used & 10.0 \\
\hline Model: nondispersion (ND) or mass-balance $(\mathrm{MB})^{\mathrm{b}}$ & - & Not used & Not used & ND model \\
\hline Number of unsaturated zone strata & - & Not used & Not used & 1 \\
\hline Unsaturated zone 1 , thickness ${ }^{\mathfrak{a}}$ & $\mathbf{m}$ & Not used & Not used & 13.7 \\
\hline Unsaturated zone 1 , soil density & $\mathrm{g} / \mathrm{cm}^{3}$ & Not used & Not used & 1.35 \\
\hline Unsaturated zone 1 , total porosity ${ }^{a}$ & $\cdot$ & Not used & Not used & 0.4 \\
\hline Unsaturated zone 1 , effective porosity ${ }^{a}$ & - & Not used & Not used & 0.2 \\
\hline Unsaturated zone 1 , soil-specific b parameter ${ }^{a}$ & - & Not used & Not used & 7.12 \\
\hline Unsaturated zone 1 , hydraulic conductivity ${ }^{a}$ & $\mathrm{~m} / \mathrm{yr}$ & Not used & Not used & 200 \\
\hline Distribution coefficient & $\mathrm{cm}^{3} / \mathrm{g}$ & & & \\
\hline \multicolumn{5}{|l|}{ Contaminated zone } \\
\hline Strontium-90 & & 7 & 7 & 7 \\
\hline Cesium-137 ${ }^{b}$ & & 1,000 & 1,000 & 1,000 \\
\hline \multicolumn{5}{|l|}{ Saturated zone } \\
\hline Strontium-90 & & 7 & 7 & 7 \\
\hline Cesium-137 & & 1,000 & 1,000 & 1,000 \\
\hline \multicolumn{5}{|l|}{ Unsaturated zone } \\
\hline Strontium-90 & & 7 & 7 & 7 \\
\hline Cesium-137 & & 1,000 & 1,000 & 1,000 \\
\hline Inhalation rate ${ }^{b}$ & $\mathrm{~m}^{3} / \mathrm{yr}$ & 8,400 & 8,400 & 8,400 \\
\hline Mass loading for inhalation ${ }^{b}$ & $\mathrm{~g} / \mathrm{m}^{3}$ & 0.0002 & 0.0002 & 0.0002 \\
\hline Shielding factor, inhalation ${ }^{b}$ & 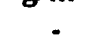 & 0.4 & 0.4 & 0.4 \\
\hline Shielding factor, external gamma ${ }^{b}$ & - & 0.7 & 0.7 & 0.7 \\
\hline Time fraction, indoors ${ }^{a}$ & - & 0.057 & 0 & 0.5 \\
\hline Time fraction, outdoors ${ }^{a}$ & - & 0.171 & 0.086 & 0.25 \\
\hline Shape factor, external gamma ${ }^{b}$ & - & 1 & 1 & 1 \\
\hline Dilution length for airborne dust, inhalation ${ }^{b}$ & m & 3 & 3 & 3 \\
\hline
\end{tabular}




\begin{tabular}{|c|c|c|c|c|}
\hline \multirow[b]{2}{*}{ Parameter } & \multirow[b]{2}{*}{ Unit. } & \multicolumn{3}{|c|}{ Value } \\
\hline & & Scenario A & Scenario B & Scenario C \\
\hline Fruit, vegetable, and grain consumption ${ }^{b}$ & $\mathrm{~kg} / \mathrm{yr}$ & Not used & Not used & 160.0 \\
\hline Leafy vegetable consumption ${ }^{b}$ & $\mathrm{~kg} / \mathrm{yr}$ & Not used & Not used & 14.0 \\
\hline Milk consumption & $\mathrm{L} / \mathrm{yr}$ & Not used & Not used & 92.0 \\
\hline Meat and poultry consumption ${ }^{b}$ & $\mathrm{~kg} / \mathrm{yr}$ & Not used & Not used & 63 \\
\hline Fish consumption & $\mathrm{kg} / \mathrm{yr}$ & Not used & Not used & 5.4 \\
\hline Other seafood consumption ${ }^{b}$ & $\mathrm{~kg} / \mathrm{yr}$ & Not used & Not used & 0.9 \\
\hline Soil ingestion ${ }^{b}$ & $\mathrm{~g} / \mathrm{yr}$ & 36.5 & 36.5 & 36.5 \\
\hline Drinking water intake $e^{b}$ & $\mathrm{~L} / \mathrm{yr}$ & Not used & Not used & 510 \\
\hline Fraction of drinking water from site ${ }^{b}$ & - & Not used & Not used & 1.0 \\
\hline Fraction of aquatic food from site ${ }^{b}$ & - & Not used & Not used & 0.5 \\
\hline Livestock fodder intake for meat & $\mathrm{kg} / \mathrm{d}$ & Not used & Not used & 68.0 \\
\hline Livestock fodder intake for milkb & $\mathrm{kg} / \mathrm{d}$ & Not used & Not used & 55.0 \\
\hline Livestock water intake for meat & $\mathrm{L} / \mathrm{d}$ & Not used & Not used & 50.0 \\
\hline Livestock water intake for milk ${ }^{b}$ & $\mathrm{~L} / \mathrm{d}$ & Not used & Not used & 160.0 \\
\hline Mass loading for foliar deposition ${ }^{b}$ & $\mathrm{~g} / \mathrm{m}^{3}$ & Not used & Not used & 0.0001 \\
\hline Depth of soil mixing layer ${ }^{b}$ & $\mathrm{~m}$ & 0.15 & 0.15 & 0.15 \\
\hline Depth of roots ${ }^{b}$ & m & Not used & Not used & 0.9 \\
\hline \multicolumn{5}{|l|}{$\begin{array}{l}\text { Groundwater fractional usage (balance } \\
\text { from surface water): }\end{array}$} \\
\hline Drinking water & & Not used & Not used & 1.0 \\
\hline Livestock water & & Not used & Not used & 1.0 \\
\hline Irrigation ${ }^{\mathbf{a}}$ & & Not used & Not used & 1.0 \\
\hline Total porosity of the cover material ${ }^{b}$ & - & Not used & Not used & Not used \\
\hline Total porosity of the house or building foundation ${ }^{b}$ & - & Not used & Not used & Not used \\
\hline Volumetric water content of the cover material ${ }^{b}$ & $\cdot$ & Not used & Not used & Not used \\
\hline Volumetric water content of the foundation ${ }^{b}$ & $\cdot$ & Not used & Not used & Not used \\
\hline Diffusion coefficient for radon gas: & $\mathrm{m} / \mathrm{s}$ & & & \\
\hline In cover material ${ }^{b}$ & & Not used & Not used & Not used \\
\hline In foundation material ${ }^{b}$ & & Not used & Not used & Not used \\
\hline In contaminated zone soil ${ }^{b}$ & & Not used & Not used & Not used \\
\hline Emanating power of radon-222 & - & Not used & Not used & Not used \\
\hline Emanating power of radon $-220^{\mathrm{b}}$ & - & Not used & Not used & Not used \\
\hline Radon vertical dimension of mixing ${ }^{b}$ & $\mathbf{m}$ & Not used & Not used & Not used \\
\hline Average annual wind speed ${ }^{b}$ & $\mathrm{~m} / \mathrm{s}$ & Not used & Not used & Not used \\
\hline Average building air exchange rate ${ }^{b}$ & $h^{-1}$ & Not used & Not used & Not used \\
\hline Height of building (room) & $\mathrm{m}$ & Not used & Not used & Not used \\
\hline Building indoor area factor ${ }^{b}$ & $\cdot$ & Not used & Not used & Not used \\
\hline Bulk density of house or building foundation ${ }^{b}$ & $\mathrm{~g} / \mathrm{cm}^{3}$ & Not used & Not used & Not used \\
\hline Thickness of house or building foundation ${ }^{b}$ & $\mathrm{~m}$ & Not used & Not used & Not used \\
\hline Building depth below ground surface ${ }^{b}$ & m & Not used & Not used & Not used \\
\hline
\end{tabular}

a Values based on site specifications or scenario assumptions.

b RESRAD default values. 

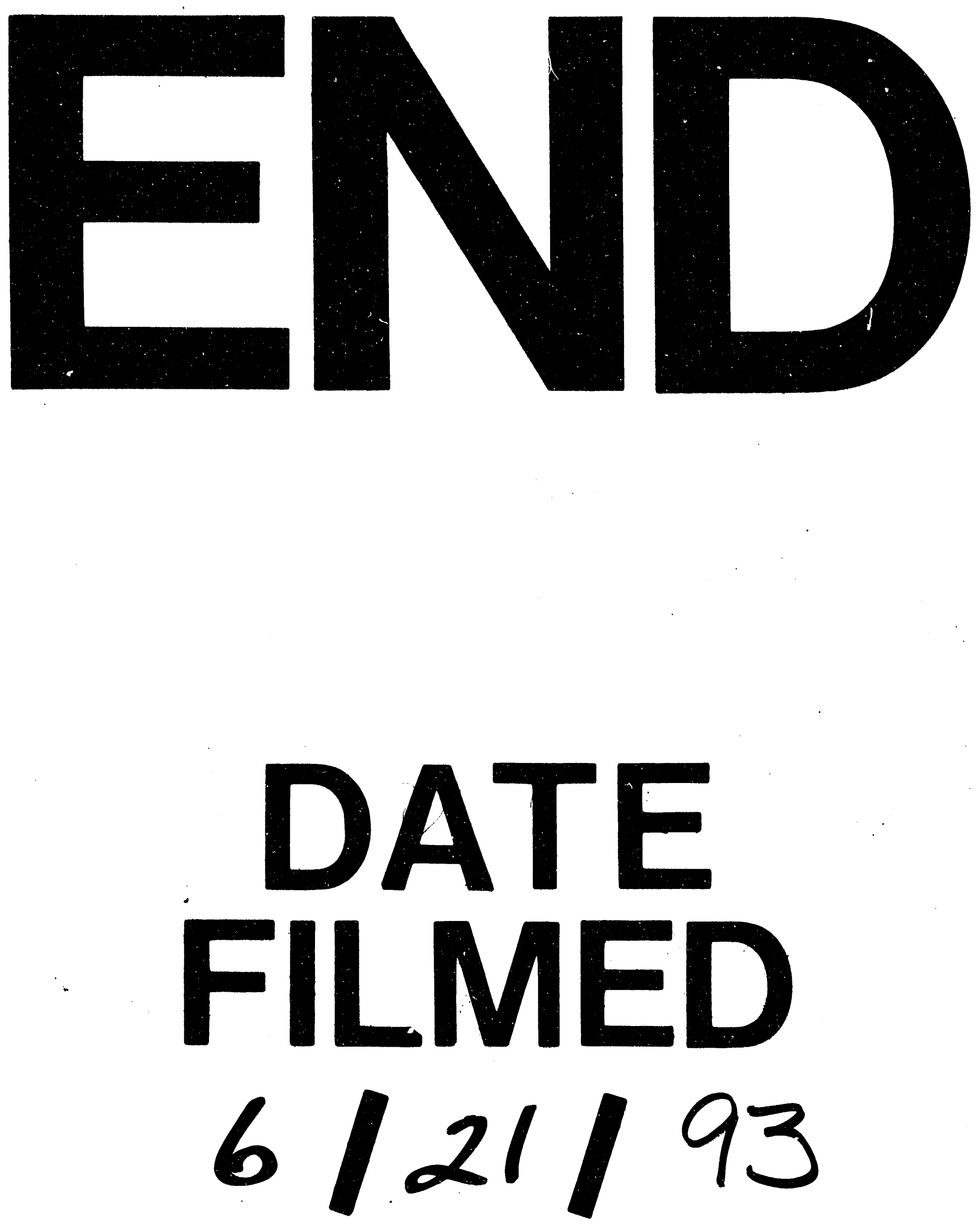


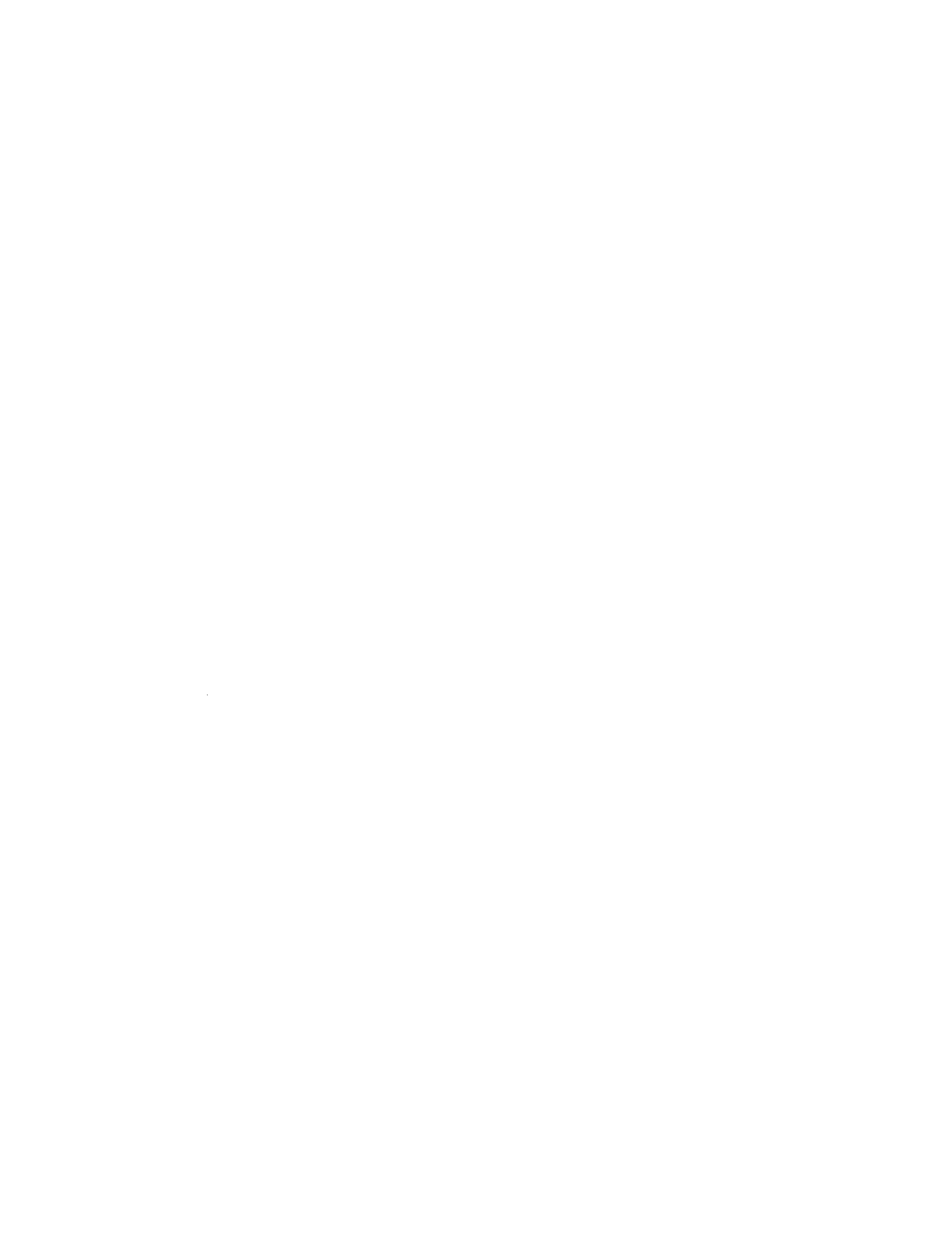

